\title{
On the concentration and size distribution of sub-micron aerosol in the Galápagos Islands
}

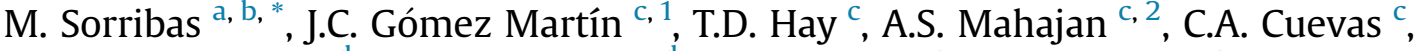 \\ M.V. Agama Reyes ${ }^{d}$, F. Paredes Mora ${ }^{\text {d }}$, M. Gil-Ojeda ${ }^{\text {e, A. Saiz-Lopez }}{ }^{\text {c }}$ \\ a Department of Applied Physics, University of Granada, Granada, 18071, Spain \\ ${ }^{\mathrm{b}}$ Andalusian Institute for Earth System Research (IISTA), University of Granada, 18006, Spain \\ ${ }^{c}$ Atmospheric Chemistry and Climate Group, Institute of Physical Chemistry Rocasolano, CSIC, Madrid, Spain \\ ${ }^{\mathrm{d}}$ National Institute for Meteorology and Hydrology (INAMHI), Quito, Ecuador \\ e Atmospheric Research and Instrumentation Branch, National Institute for Aerospace and Technology (INTA), Madrid, Spain
}

\section{H I G H L I G H T S}

- First measurements of aerosol concentrations in the Galapagos Islands are shown.

- No evidence of new-formed particles in the marine boundary layer (MBL) was observed.

- Aitken mode in the MBL was aerosol from the free troposphere off the coast of Chile.

- Cloud processing in the MBL increases the concentration in the accumulation mode.

- Particle formation was triggered by biogenic emissions from the island's lowlands.

\section{A R T I C L E I N F O}

\section{Article history:}

Received 31 March 2015

Received in revised form

8 October 2015

Accepted 10 October 2015

Available online 22 October 2015

\section{Keywords:}

Sub-micrometre particle

SMPS

Marine boundary layer

\begin{abstract}
A B S T R A C T
During the CHARLEX campaign in the Galápagos Islands, a Scanning Particle Mobility Sizer was deployed on San Cristobal Island in July-August 2011 to carry out size-resolved measurements of the concentration of submicron aerosols. To our knowledge these are the first measurements of aerosol concentrations in this unique environment. The particles with marine origin displayed a tri-modal number size distribution with peak diameters of $0.016 \mu \mathrm{m}, 0.050 \mu \mathrm{m}$ and $0.174 \mu \mathrm{m}$ and a cloud-processed intermodal minimum at $0.093 \mu \mathrm{m}$. The mean total aerosol number concentration for the marine contribution was $470 \pm 160 \mathrm{~cm}^{-3}$. A low particle concentration of $70 \pm 50 \mathrm{~cm}^{-3}$ for the nucleation size range was measured, but no evidence of new particle production in the atmospheric marine boundary layer (MBL) was observed. The concentration of the Aitken size mode was found to be related to aerosol entrainment from the free troposphere off the coast of Chile followed by transport within the MBL to the Galápagos Islands. Cloud processing may activate the particles in the Aitken size range, growing through 'in-cloud' sulphate production and increasing the particle concentration in the accumulation size range. The $0.093 \mu \mathrm{m}$ cloud processed minima suggests that the critical supersaturation at which the particle is activated to a cloud droplet is in the $0.14-0.21 \%$ range. The daytime marine particle background concentration was influenced by human activity around the sampling site, as well as by new particle formation triggered by biogenic emissions from the vegetation cover of the island's semiarid lowlands. Effective CCN formation may play a role in the formation and properties of the stratus clouds, which permanently cover the top of the windward side of the islands and establish one of their characteristic climatic bands.
\end{abstract}

(c) 2015 Elsevier Ltd. All rights reserved.

\footnotetext{
* Corresponding author. Department of Applied Physics, University of Granada, 18071, Granada, Spain.

E-mail address: sorribas@ugr.es (M. Sorribas).

1 Currently at: School of Chemistry, University of Leeds, Leeds, UK.

2 Currently at: Indian Institute of Tropical Meteorology (IITM), Pune, India.
}

\section{Introduction}

CHARLEX (Climate and HAlogen Reactivity tropicaL Experiment) was a ground-based study of the composition and chemistry of the atmospheric marine boundary layer (MBL) carried out in the 
Galápagos Islands (Ecuador) from September 2010 to February 2012 (Gómez Martín et al., 2013). The primary objective of the campaign was to study the temporal evolution of the mixing ratios of reactive halogen species in the Eastern Pacific MBL. The collected data, combined with spatially resolved data from the same region (Mahajan et al., 2012) and other locations around the world (Prados-Roman et al., 2015), has enabled new insights into the emission of reactive iodine precursors from the ocean (Carpenter et al., 2013; MacDonald et al., 2014). Other important conclusions of the study were the observations of low iodine monoxide (IO) mixing ratios, which are insufficient to sustain iodine oxide particle (IOP) formation over the open ocean (Mahajan et al., 2010) and also rule out the MBL as the location of high IO column densities detected from space over the Eastern Pacific (Schönhardt et al., 2008). Finally, the contribution of iodine and bromine to surface ozone $\mathrm{O}_{3}$ depletion was quantified.

In order to investigate a potential presence of IOPs in the open ocean MBL, measurements of sub-micron particle size distribution were performed for three weeks during the summer 2011 at San Cristobal Island. Significant advances have been made during recent years in identifying particle production in coastal zones (e.g. O'Dowd and de Leeuw, 2007; Mahajan et al., 2011; Sorribas et al., 2011, 2015), where iodine oxides and anthropogenic emissions are the dominant species leading to particle production. However studies in the open ocean are still scarce. New particle production and growth events have been observed during periods of high oceanic productivity over the N.E. Atlantic (Ehn et al., 2010; O'Dowd et al., 2010), although the absence of such processes is the usual pattern (e.g. Raes et al., 1997; Tomlinson et al., 2007).

The investigation of potential IOP-related new particle formation over the Eastern Pacific during CHARLEX was complemented with the study of more general issues relevant for the global aerosol budget. Besides new particle formation, field aerosol size distributions encompass many other atmospheric processes including condensation, coagulation or cloud processing.

Given that $70 \%$ of the Earth's surface is covered by oceans, marine aerosols are thought to play a key role in climate both through direct and indirect effects. Global climate models and satellite retrievals (Myhre et al., 2007; Ma et al., 2008) require information about particle size to enable calculations of the impact of aerosols on the atmospheric radiative transfer. Field campaigns provide key experimental data of aerosol properties based on location and source region as determined by air mass back trajectories (e.g. McGovern et al., 1999; Bates et al., 2002).

The main objective of the present paper is reporting in detail the aerosol measurements carried out during CHARLEX. The absence of open ocean nucleation events, consistent with generally low IO mixing ratios implying slow IOP growth, was briefly reported by (Gómez Martín et al., 2013). Here, besides a more detailed discussion of the lack of newly-formed particles, the modal and total particle concentration and the sub-micron size distribution variability in the Galápagos Islands are reported and discussed in terms of aerosol dynamic processes and transport patterns.

\section{Materials and methods}

\subsection{Sampling sites and meteorology}

The Galápagos Archipelago is a group of volcanic islands located in the East Equatorial Pacific, $1000 \mathrm{~km}$ west of the Ecuadorian coast. The unique regional climate is determined by the interaction of ocean currents and winds, governed by the seasonal shift of the Inter-Tropical Convergence Zone, and strongly influenced by the El Niño Southern Oscillation (ENSO) (Alpert, 1963). The aerosol measurements reported in this study were carried out at the onset of the cold/dry season (July-August) of an ENSO-neutral year (2011) (NOAA ENSO Diagnostic Discussions, 2011). Under these conditions, the southern shores of the islands were permanently subjected to the prevailing south-easterly trade winds and the air masses reaching the coast can be considered to be representative of the background south-eastern open ocean.

San Cristóbal is the easternmost and fifth largest island of the archipelago. Puerto Baquerizo Moreno $\left(0^{\circ} 54^{\prime} 14.53^{\prime \prime} \mathrm{S}\right.$, $\left.89^{\circ} 36^{\prime} 50.92^{\prime \prime} \mathrm{W}\right)$ is the only town of the island, situated in Shipwreck Bay on the south-western coast. The dry lowlands surrounding the town are characterized by nanophyllous desert scrub vegetation (Hamann, 1979). The sampling site (hereafter SCR-PBM) was placed in the permanently manned meteorological station of the National Institute for Meteorology and Hydrology (INAMHI) (WMO 84008), to the west of the town at 6 m elevation above mean sea level. Given the situation of the station and the prevailing wind direction during the campaign, the site can be classified as background rural area with a low urban influence (Fig. 1), and a natural contribution to the aerosol loading coming from the south of the island composed of biogenic emissions should be also taken into account. A second sampling site was located at La Lobería beach (hereafter SCR-LBR), which is $2.1 \mathrm{~km}$ south of SCR-PBM and can be considered as representative of background marine aerosol.

Back-trajectories analysis was used to characterise the origin and the path of the air masses arriving at both sampling sites. The $120 \mathrm{~h}$ back-trajectories were calculated using HYSPLIT (Hybrid Single Particle Lagrangian Integrated Trajectory) (Draxler and Hess, 1998), with the vertical velocity field from the Global Data Assimilation System (GDAS) meteorological data. Fig. 2a shows the calculated back-trajectories arriving at 12:00 UTC for the overall period of the campaign, which come from the open ocean having previously travelled parallel to the coast of Chile and Peru. The only significant difference between the back-trajectories arriving at each site is the strip of land over which the air masses pass before arriving at SCR-PBM (Fig. 2b and c). This area on San Cristóbal Island is covered by a relatively dense desert scrub and therefore, biogenic emissions can be expected to modify the marine background levels. In this context, the particle number size distributions measured at SCR-PBM are classified according to the intensity of the particle source as follows: (a) daytime observations, comprising a complex mix of aerosol state classes with a variety of particle sources (marine, rural and biogenic) and (b) night time, representative of the marine background aerosol. At SCR-LBR, marine background

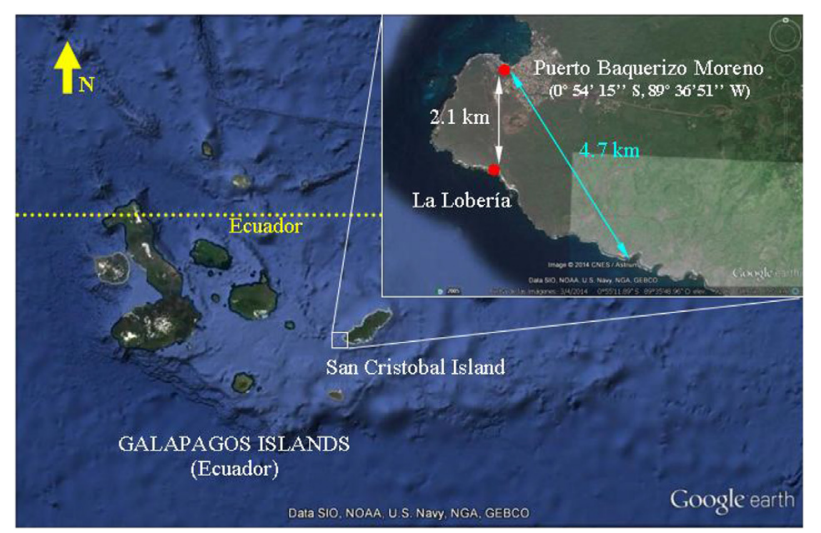

Fig. 1. CHARLEX study area at San Cristóbal Island showing the measurement sites at Puerto Baquerizo Moreno (SCR-PBM) and La Lobería (SCR-LBR). The light blue line indicates the typical wind direction and the distance travelled by the air masses on the ground, before arriving at SCR-PBM. (For interpretation of the references to colour in this figure legend, the reader is referred to the web version of this article.) 


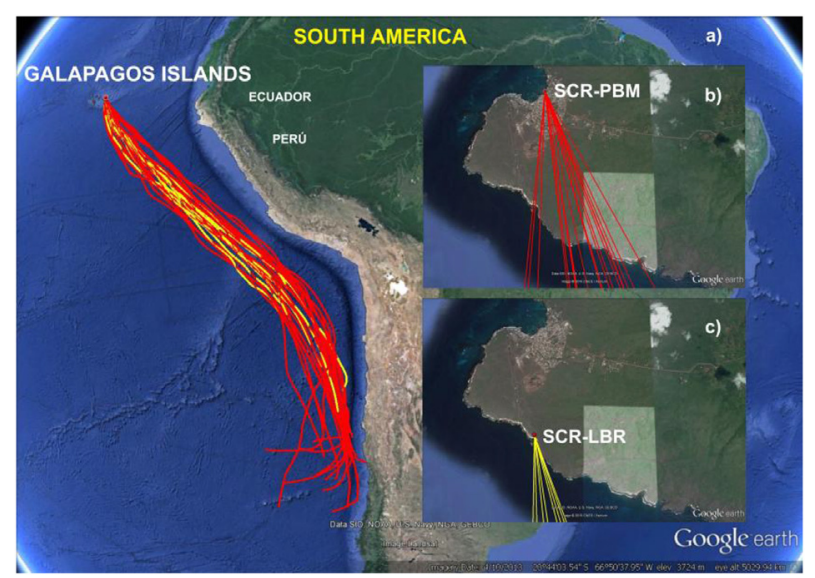

Fig. 2. (a) Air mass trajectory at surface level identified according to the 5-day backtrajectories calculated with HYSPLIT model. (b) Final section of the back-trajectories arriving at SCR-PQM and (c) SCR-LBR.

aerosol can be considered as the only contribution to both day- and night time observations.

\subsection{Instrumentation}

Surface aerosol measurements were carried out at SCR-PBM and SCR-LBR. At SCR-PBM, the inlet was placed at about $6 \mathrm{~m}$ above ground level. The aerosol sampling was carried out by means of a vertical stainless steel pipe $(1 \mathrm{~cm}$ inner diameter and $150 \mathrm{~cm}$ length) with a flow rate of $121 \mathrm{~min}^{-1}$, resulting in a Reynolds number of 1700 . The sampled air flow was subsequently split in two and conducted via air dryers to a Scanning Mobility Particle Sizer (SMPS) and an Ultrafine Condensation Particle Counter (UCPC). At SCR-LBR, the inlet was located on top of the instrument container, about $3 \mathrm{~m}$ above ground level and $100 \mathrm{~m}$ away from the shoreline. The sampled aerosol was drawn into the UCPC inlet through a $1.5 \mathrm{~m}$ long stainless steel pipe with $4 \mathrm{~mm}$ inner diameter. The sampling system efficiency (including the dryers) was calculated according to the AEROCAL program available from P. Baron's website: Www.aerosols.wustl.edu/AAARworkshop08/html/ calculator.htm.

The sub-micron particle number size distribution in the 9-407 $\mathrm{nm}$ range was monitored using a SMPS, which consists of an Electrostatic Classifier (TSI Model 3080) and an UCPC (TSI Model 3776). The sheath flow was $6.0 \mathrm{l} \mathrm{min}^{-1}$ and it was dried with silica gel in a closed loop. The sampled aerosol flow was $0.61 \mathrm{~min}^{-1}$ and it was dried below $40 \%$ relative humidity using a Perma Pure Nafion sample air dryer (Perma Pure Inc., Toms River, N). As a result of the different operational flows of the Electrostatic Classifier and the UCPC, an excess and filtered flow of $0.91 \mathrm{~min}^{-1}$ was added using a critical orifice to control the flow, upstream of the UCPC inlet. The SMPS data were corrected for losses caused by diffusion and multiple charges inside the instrument using the AIM software (version 9.0.0, TSI, Inc., St Paul, MN, USA). A second UCPC was used to measure the total concentration of particles larger than $3 \mathrm{~nm}(50 \%$ detection at $3 \mathrm{~nm}$ ). The aerosol sampled by this second UCPC was also dried using a Perma Pure Dryer. The difference in total particle concentration between the UCPC and SMPS systems gives the particles in the (3-9) nm size range. The responses of the SMPS and the UCPC were cross-compared previous to the CHARLEX campaign following the guidelines of the Spanish Network on Environmental DMAs (Gómez-Moreno et al., 2015). Additionally, both UCPCs were compared at their arrival at the Galapagos Islands, showing deviations below $8 \%$.
The SMPS system was running from 30 July to 5 August 2011 at SCR-PBM. The UCPC system ran from 21 July to 10 August at SCRPBM and from 6 to 10 August at SCR-LBR. For analytical purposes, particle number size distributions are assumed to have four-size fractions: the nucleation size fraction (3-9) $\mathrm{nm}$, the aged nucleation size fraction $(9-30) \mathrm{nm}$, the Aitken size fraction $(30-100) \mathrm{nm}$ and the accumulation size fractions $(100-473 \mathrm{~nm})$. The particle concentrations within these four size fractions are denoted by $\mathrm{N}_{\mathrm{NUC}}, \mathrm{N}_{\mathrm{NUC}}^{\mathrm{AGE}}, \mathrm{N}_{\mathrm{AIT}}$ and $\mathrm{N}_{\mathrm{ACC}}$, respectively. The term 'mode' was used to describe each mode of the size distribution function when it was log-normal fitted.

In addition to the particle instruments, the solar radiation was measured using a global radiometer (Kipp \& Zonen CPM11) and the ozone concentration was measured with a UV absorption monitor (2BT 205). Meteorological data (pressure, temperature, relative humidity, precipitation, wind speed (WS) and direction and sea surface temperature (SST)) were provided by the INAMHI weather station at SCR-PBM at 6:00, 09:00, 12:00, 15:00 and 18:00 local time (no night time data).

\section{Results and discussion}

\subsection{Aerosol size distributions and concentrations}

Time series of the total particle concentration with diameter larger than $3 \mathrm{~nm}\left(\mathrm{~N}_{3}\right)$ and global solar radiation recorded at SCRPBM during the CHARLEX campaign are shown in Fig. 3a. The mean value for $\mathrm{N}_{3}$ was $1600 \pm 1300 \mathrm{~cm}^{-3}$ ( \pm indicates one standard deviation). The median value was $1200 \mathrm{~cm}^{-3}$ with 16 th and 84 th percentiles of $260 \mathrm{~cm}^{-3}$ and $3000 \mathrm{~cm}^{-3}$, respectively. The daily cycle of $\mathrm{N}_{3}$ shows the minimum hourly mean levels during the night from 00:00 LT to 04:00 LT with a mean value of $270 \mathrm{~cm}^{-3}$. An increase is observed in the early morning when the sunrise starts at 06:00 LT, reaching the maximum at 08:00 LT with $3600 \mathrm{~cm}^{-3}$. Later, the $\mathrm{N}_{3}$ decreased slowly to reach the levels usually observed during the night at 23:00 LT. The daily evolution observed from 06:00 LT to 23:00 LT is attributed to the contribution of several aerosol sources such as marine, rural and biogenic, and from 00:00 LT and 04:00 LT to the marine background source only. This is discussed in detail in Section 3.2 .

From 6 to 10 August, $\mathrm{N}_{3}$ was also monitored at the SCR-LBR site (blue dots in Fig. 3a). The mean value for $\mathrm{N}_{3}$ was $470 \pm 160 \mathrm{~cm}^{-3}$ and a daily evolution was not observed. Taking into account the pathway of the air masses arriving at the sampling area (Fig. 2), the particle levels can be considered as a background marine contribution. Additionally, the $\mathrm{N}_{3}$ levels observed at SCR-LBR were a factor 1.8 higher than those observed at SCR-PBM during the night. These differences in $\mathrm{N}_{3}$ levels will be analysed in Section 3.2.1.

The sub-micron particle number size distribution was measured at SCR-PBM from 30 July to 5 August. In Fig. 4 the colour surface plot (top panel) and the evolution of the particle concentration for nucleation, aged nucleation, Aitken and accumulation size fractions $\left(\mathrm{N}_{\mathrm{NUC}}, \mathrm{N}_{\mathrm{NUC}}^{\mathrm{AG}}, \mathrm{N}_{\mathrm{AIT}}\right.$ and $\left.\mathrm{N}_{\mathrm{ACC}}\right)$ are shown. The daily mean cycle evolution of $\mathrm{N}_{3}$ was dominated mainly by particles with diameters lower than $30 \mathrm{~nm}$, e.g., the nucleation and aged nucleation size fractions, during the day. At night, the concentration was dominated mainly by $\mathrm{N}_{\mathrm{NUC}}, \mathrm{N}_{\mathrm{AIT}}$ and $\mathrm{N}_{\mathrm{ACC}}$ (this is not appreciated in the bottom panel of Fig. 4 due to the scale), with $70 \pm 50 \mathrm{~cm}^{-3}$, $80 \pm 30 \mathrm{~cm}^{-3}$ and $73 \pm 21 \mathrm{~cm}^{-3}$. The N NUE was lower with $36 \pm 24 \mathrm{~cm}^{-3}$. Higher night time $\mathrm{N}_{\mathrm{ACC}}$ was only observed between 30 July and 1 August (see Fig. 4 top panel).

Fig. 5 shows the mean number particle size distribution, with each curve representing two different time segments of the day, which are characterized by different particle sources (see Section 3.2). A tri-modal particle number size distribution function was 

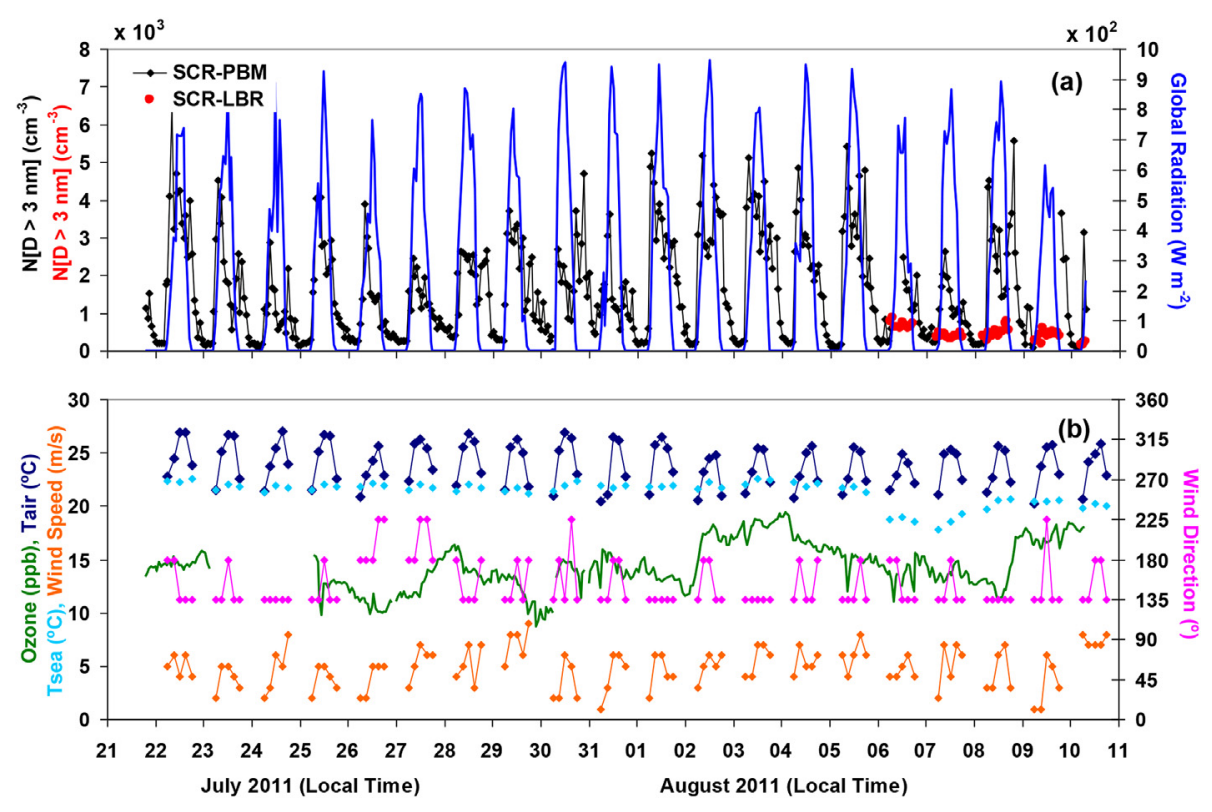

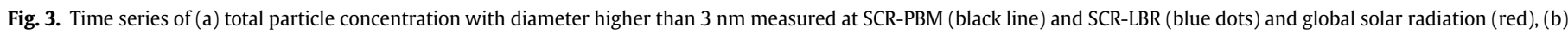

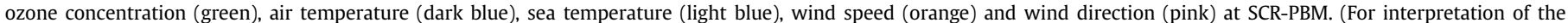
references to colour in this figure legend, the reader is referred to the web version of this article.)
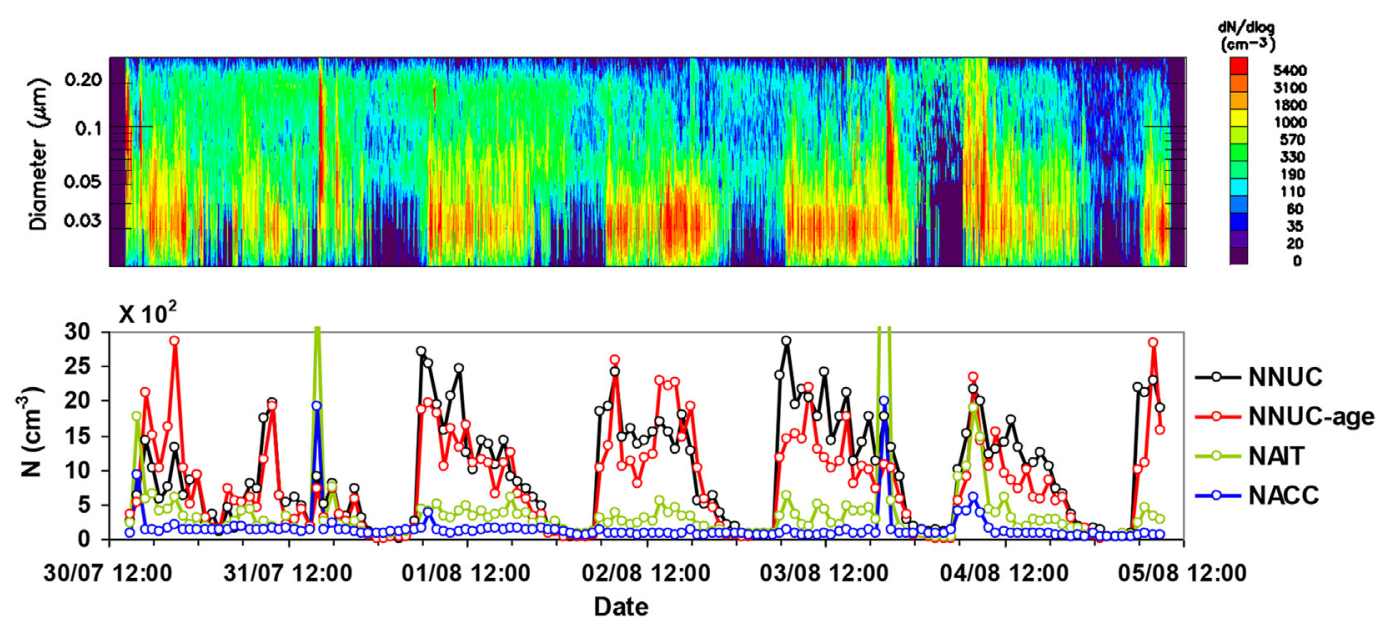

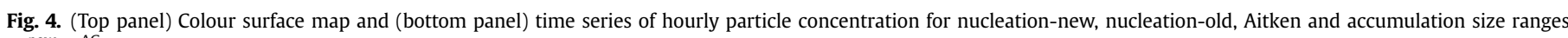

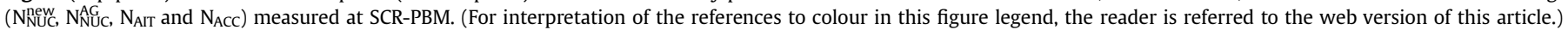

observed in the MBL aerosol (mean 00:00-05:00 LT), Fig. 5, with the first mode (nucleation) centred at a diameter of $0.016 \mu \mathrm{m}$, the second mode (Aitken) at $0.050 \mu \mathrm{m}$ and the third mode (accumulation) at $0.174 \mu \mathrm{m}$. The inter-modal minima occurred at $0.022 \mu \mathrm{m}$ and at $0.093 \mu \mathrm{m}$, between the nucleation and Aitken modes and the Aitken and accumulation modes, respectively.

A comparison of the number size distributions found in the study area with those observed in other marine environments has been carried out. Similar modal structures have been previously reported in the subtropical Northeast Atlantic (Raes et al., 1997), in the Indian Ocean (Bates et al., 2002) and in the Pacific (Clarke et al., 2006), showing Aitken and accumulation modes with similar mean geometric diameters and an inter-modal minimum around 60-80 $\mathrm{nm}$. The modal parameters corresponding to each mean size distribution, based on fits of the tri-modal particle number size distribution function to the measured distributions are shown in Table 1 . For the mixed air mass category, the total concentration increases within all modes and the Aitken and accumulation modes are shifted to smaller diameters. In a more anthropogenized maritime environment in the Mediterranean area, the aerosol number distribution consisted of nucleation, Aitken and accumulation modes with a number concentration significantly higher than that encountered in the marine category (Piazzola et al., 2012). This comparison indicates that the marine category is not impacted by pollution transported over the Pacific Ocean as was found over the Mediterranean Sea. In addition, the new particle formation events that seem to take place over the Mediterranean Sea are not observed over our sampling area.

\subsection{Discussion of the particle contribution analysis}

\subsubsection{Marine aerosol}

In the MBL, the ocean is not the only particle source. The stable shape of the number particle size distribution under marine 


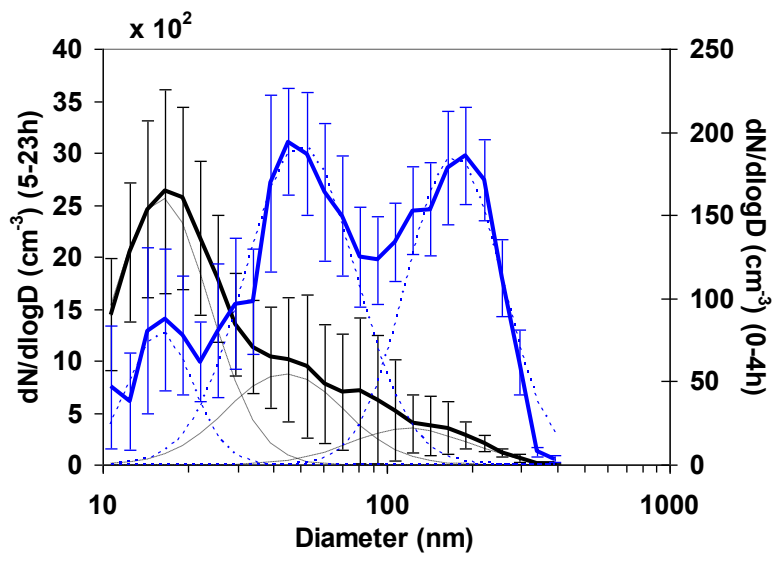

Fig. 5. Number size distribution for marine (blue line) background air masses and a mix of marine, rural and biogenic contributions (black line) at SCR-PBM. The vertical bars represent one standard deviation in the mean number in that bin size over the averaging period (Marine $-25 \mathrm{hr}$, Mixed $-108 \mathrm{~h}$ ). The fitting number size distributions of the three-lognormal modes for both contributions are in dashed lines, corresponding to the modal parameters in Table 1. (For interpretation of the references to colour in this figure legend, the reader is referred to the web version of this article.)

conditions reported throughout the literature could result from four possible atmospheric processes contributing to particle concentration: (1) new particle formation driven by sulphuric acid and iodine oxides resulting from emissions of DMS and iodine-bearing molecules from the ocean surface, facilitated by the presence of other condensable compounds such as organic products from isoprene oxidation (Russell et al., 1994; O'Dowd and de Leeuw, 2007; Mahajan et al., 2011), (2) entrainment of particles from the free troposphere (FT) (Raes et al., 1997), (3) aqueous-phase chemistry on non-activated aerosol which can be activated and become cloud droplets or cloud condensation nuclei (CCN) to further form stratiform clouds over the ocean (Magaritz et al., 2010), and (4) sea spray aerosol production by wind stress at the ocean surface (O'Dowd and Smith, 1993). Below, these processes are discussed in order to understand the particle contribution within each size range of the observed size distribution.

New particle formation is an infrequent process in the MBL, which is observed in the presence of low pre-existing aerosol surface area concentration (Heintzenberg et al., 2000, 2004). Aerosol dynamics calculations predict a threshold dry aerosol surface of $15 \mu \mathrm{m}^{2} \mathrm{~cm}^{-3}$ to inhibit the binary nucleation $\left(\mathrm{H}_{2} \mathrm{SO}_{4}-\mathrm{H}_{2} \mathrm{O}\right)$ under remote MBL conditions (Raes, 1995), and from experimental data this threshold has been evaluated to be $3 \mu \mathrm{m}^{2} \mathrm{~cm}^{-3}$ (O'Dowd et al., 1996). Another example is found during the two cruises described in Tomlinson et al. (2007), where a reduction in aerosol surface area from $27 \mu \mathrm{m}^{2} \mathrm{~cm}^{-3}$ to $10 \mu \mathrm{m}^{2} \mathrm{~cm}^{-3}$ accompanied the only nucleation events observed during both campaigns. Our measurements show that the mean aerosol surface of the marine contribution was $10 \pm 4 \mu \mathrm{m}^{2} \mathrm{~cm}^{-3}$, which is high enough to inhibit a strong nucleation process and the consequent growth by condensation processes. The low surface IO mixing ratios observed throughout the

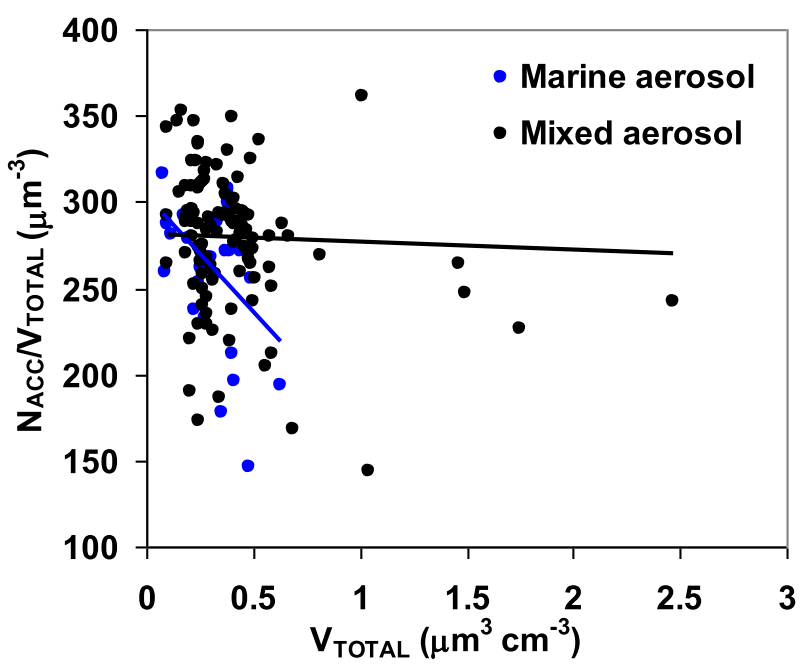

Fig. 6. Ratio of the accumulation size range concentration $\left(\mathrm{N}_{\mathrm{ACC}}\right)$ to the total volume $\left(\mathrm{V}_{\mathrm{TOTAL}}\right)$ vs. total volume concentration for both marine and mixed aerosol.

CHARLEX campaign (Gómez Martín et al., 2013) also rule out IOP nucleation (Mahajan et al., 2010).

However, a mean $\mathrm{N}_{\mathrm{NUC}}=70 \pm 50 \mathrm{~cm}^{-3}$ was observed in the marine air masses and therefore, a weak nucleation process cannot be discarded. In our study, this background concentration within the nucleation size range was not dependent on the concentration of pre-existing aerosol, since no relationship was observed with the aerosol surface concentration. Only about half of the new particles grew, resulting in an average $\mathrm{N}_{\mathrm{NUC}}^{\mathrm{AGE}}=36 \pm 24 \mathrm{~cm}^{-3}$. The rest of the new particles possibly coagulated with particles within the accumulation size range, thus resulting in an increase of the particle concentration within the coarse size range.

The low concentration of new particles raises the question about the origin of the particles within the Aitken size range. In our study, the mean $N_{\text {AIT }}$ was $76 \pm 29 \mathrm{~cm}^{-3}$, which is a factor of 2.1 higher than the mean NNGC. A potential explanation of the observed Aitken size range particles is the entrainment of pre-existing aerosol from the free troposphere (FT) and subsequent condensational growth (Raes et al., 1997). This question has been analysed in previous studies in terms of the $\mathrm{N}_{\mathrm{ACC}} / \mathrm{V}_{\mathrm{TOTAL}}$ ratio. Since $\mathrm{FT}$ air has very low $\mathrm{V}_{\mathrm{TOTAL}}$, entrainment acts as a simultaneous dilution process for $\mathrm{V}_{\mathrm{TOTAL}}$, increasing the $\mathrm{N}_{\mathrm{ACC}} / \mathrm{V}_{\mathrm{TOTAL}}$ ratio with decreasing $\mathrm{V}_{\mathrm{TOTAL}}$ (Van Dingenen et al., 2000). Such behaviour is observed in Fig. 6 for marine and mixed particle contributions. However, the behaviour for the marine source is clearer than for the mixed source, probably as a result of perturbation by other particle sources within the mixed category. Therefore, this result is consistent with entrainment of FT aerosol within the Aitken size range into the MBL, explaining the concentration observed in this Aitken size range.

Fig. 7a shows the median height of the back-trajectories vs. backward hours and Fig. 7b the median height of the MBL vs. backward hours calculated with the HYSPLIT Model. Also the 10and 90- percentiles of both median heights are shown in each

Table 1

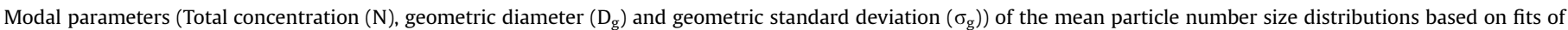
three-lognormal distributions to the data shown in Fig. 5.

\begin{tabular}{|c|c|c|c|c|c|c|c|c|c|}
\hline & \multicolumn{3}{|c|}{ Nucleation mode } & \multicolumn{3}{|c|}{ Aitken mode } & \multicolumn{3}{|c|}{ Accumulation mode } \\
\hline & $\mathrm{N} \mathrm{cm}^{-3}$ & $\mathrm{D}_{\mathrm{g}} \mathrm{nm}$ & $\sigma_{\mathrm{g}}$ & $\mathrm{N} \mathrm{cm}^{-3}$ & $\mathrm{D}_{\mathrm{g}} \mathrm{nm}$ & $\sigma_{\mathrm{g}}$ & $\mathrm{N} \mathrm{cm}^{-3}$ & $\mathrm{D}_{\mathrm{g}} \mathrm{nm}$ & $\sigma_{\mathrm{g}}$ \\
\hline Marine & 23 & 16 & 1.3 & 90 & 50 & 1.55 & 80 & 174 & 1.46 \\
\hline Mixed & 1110 & 16 & 1.49 & 450 & 44 & 1.6 & 180 & 120 & 1.6 \\
\hline
\end{tabular}



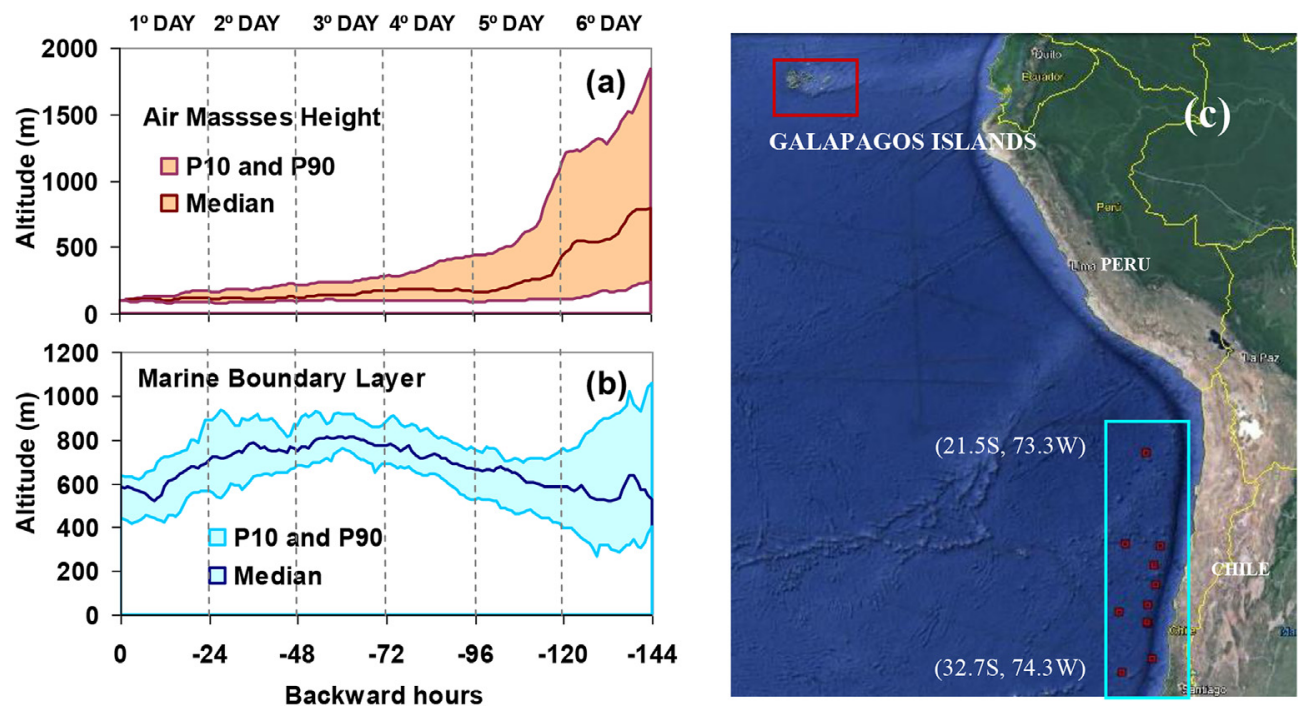

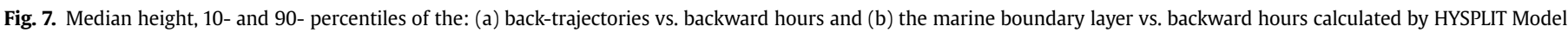
(c) Points where the intersection between the heights of the MBL and the back-trajectories are occurring.

figure. Both median heights vs. time were estimated using the height of 1-day back-trajectory at 00:00 LT for each day during the campaign. Fig. 7a shows that the height of an air parcel decreased considerably during the 6th and 5th day before the arrival to the sampling site. This descent of the air masses is linked to the usual global and tropical atmospheric circulation pattern at latitudes $\sim 30^{\circ} \mathrm{S}$, which depends on the Hadley and Ferrel cells. At these latitudes, both cells result in sinking air from high altitudes to the ground level and therefore, tropospheric entrainment is proposed as an aerosol source at ground level. Additionally, Fig. 7b shows that the MBL heights were estimated to be between $500 \mathrm{~m}$ and $800 \mathrm{~m}$, which compare reasonably well with those derived by Zeng et al. (2004).

The transport from the FT to the MBL seemed to occur as an injection (punctual entrainment) or as a continuous entrainment at the place where the intersection between the heights of the MBL and the back-trajectories occurs (red points in Fig. 7c). Thus, the aerosol is likely to be entrained in the MBL off the coast of Chile and later transported within the MBL to the Galápagos Islands. It cannot be ruled out that during the entrainment, a nucleation process forms new particles, however condensation, coagulation and cloud processing would increase the size of the newly formed particles before arriving at the sampling site.

The minimum observed between the second and third modes (Fig. 5) is the so-called Hoppel minimum, which has been frequently observed in the MBL (Hoppel et al., 1986). It has been hypothesized that particles previously within the Aitken mode may become activated, resulting in cloud droplet formation followed by the growth of accumulation mode particles by aqueous phase processes and coagulation (Mochida et al., 2011). Over time, this growth process results in the Hoppel minimum, which is the size separation between previously activated and inactivated sizes. Thus, if measurements of cloud droplet concentration are not available, the accumulation size range concentration is expected to be equivalent to the $\mathrm{CCN}$ concentration at the peak in-cloud supersaturation (Hoppel et al., 1986). Moreover, following the criteria used by Van Dingenen et al. (1995), the likely CCN concentration peak can be estimated at two supersaturation values of $0.15 \%$ and $0.75 \%$, which are assumed to be all particles above $100 \mathrm{~nm}$ and $40 \mathrm{~nm}$, respectively. During our study, the CCN concentration at $0.15 \%$ supersaturation was in the range of $20-130 \mathrm{~cm}^{-3}$ (mean \pm standard deviation $=80 \pm 32 \mathrm{~cm}^{-3}$ ), which is in agreement with previous campaigns over the Central Southern Pacific (Hoppel et al., 1986). The analysis gives a mean CCN concentration at $0.75 \%$ supersaturation of $150 \pm 70 \mathrm{~cm}^{-3}$ with minimum and maximum values of $39 \mathrm{~cm}^{-3}$ and $327 \mathrm{~cm}^{-3}$, respectively.

One of the properties that can be used to characterise the CCN activity of an aerosol is the critical supersaturation, being the lowest supersaturation at which the particle is activated to a cloud droplet. The critical supersaturation $\left(\mathrm{SS}_{\text {critical }}\right)$ is described by Köhler Theory (Köhler, 1936) and a simple parameterization to the evaluation can be found in Hoppel et al. (1996), using the following equation for ammonium sulphate aerosols:

$S S_{\text {critical }}(\%)=\left[K\left(\frac{D_{\min }}{2} \times 10^{-4}\right)^{-3 / 2}\right] \times 100$

where $\mathrm{K}=1.71 \times 10^{-11} \mathrm{~cm}^{3 / 2}$ and $\mathrm{D}_{\min }$ is the Hoppel minimum in $\mu \mathrm{m}$. The critical supersaturation in our study was calculated assuming that the particle concentration is dominated by ammonium sulphate aerosols and the Hoppel minimum was observed in the size range of $(0.081-0.108) \mu \mathrm{m}$ (if the minimum diameter and the adjacent SMPS channels are considered, Fig. 4a). The value obtained is in the range $0.14-0.21 \%$. It should be noted that these supersaturations are lower than those evaluated by Blot et al. (2013) during an aircraft campaign at $150 \mathrm{~m}$ altitude, being the range of observed values between 0.20 and $0.30 \%$. This results from a shift of the Hoppel minimum to a smaller size, indicating higher critical supersaturations. These differences may be related to our minimum being shifted to larger sizes due to longer travel of the air mass over the remote ocean.

A further aerosol contribution to the accumulation size range in the MBL could be the sea spray aerosol (SSA) (Ovadnevaite et al., 2014). SSAs are formed by two processes: through breaking waves via bubble bursting and by direct tearing of wave crests at high WS. The SSA production and lifetime in the MBL for submicrometre particles is complex. The SSA size and concentration evolution are affected, among other factors by condensation, cloud and evaporation processes, WS and MBL dynamics. In clean marine air masses and high winds, the sea salt aerosol dominates the accumulation mode (O'Dowd and Smith, 1993) with concentrations of about $70 \mathrm{~cm}^{-3}$ (O'Dowd and de Leeuw, 1997), which is similar to 
the particle concentration for accumulation size fraction in the marine category.

The steady state dry deposition method (Smith et al., 1993) combined with the SSA flux parameterization derived by Clarke et al. (2006) can be used to estimate the contribution of SSA to the marine component. There are important uncertainties in the application of the steady state approximation and flux parameterizations (de Leeuw et al., 2014), and therefore the following calculations should be regarded as mostly qualitative. The mean number flux (F) per log D interval from the Clarke et al. (2006) parameterization was evaluated for WS $=2.5 \mathrm{~m} / \mathrm{s}$ and $5 \mathrm{~m} / \mathrm{s}$. These values are taken to be representative respectively of the minimum and maximum of the WS daily cycle at SCR-PBM. Night time meteorological data was not recorded, but from full day measurements during the previous year (Gómez Martín et al., 2013) and the WS observed at 6:00 LT, an estimated WS of $2.5 \mathrm{~m} / \mathrm{s}$ for the 0:00-4:00 LT lapse can be deduced. The daytime WS during the SCR-LBR measurement period was $(4.8 \pm 2.1) \mathrm{m} / \mathrm{s}$. The particle number size distributions obtained with the steady state method are quite similar than the observed distribution for $\mathrm{WS}=2.5 \mathrm{~m} / \mathrm{s}$ but significantly lower for WS $=5 \mathrm{~m} / \mathrm{s}$. Note that the marine contribution measured throughout the campaign has been deduced from the night time data, and therefore it has to be compared to the particle concentration obtained for $2.5 \mathrm{~m} / \mathrm{s}$. The observations of the marine aerosol at SCR-LBR were carried out during daytime and should be compared to the $5 \mathrm{~m} / \mathrm{s}$ distribution. The calculated values predict a reduction of total particle concentration for accumulation mode of one order of magnitude, depending on WS.

Besides the background open ocean production of SSA, a further flux form the surf may enhance the SSA concentration at SCR-LBR compared to SCR-PBM. De Leeuw et al. (2000) proposed a relationship between the flux in the surf zone and the associated aerosol number concentration similar to the steady state equation, but replacing the deposition velocity by the WS/L ratio, where L is the width of the surf zone. Considering the Clarke et al. (2006) flux parameterization and assuming $5 \mathrm{~m} / \mathrm{s}$ and $40 \mathrm{~m}$ for WS and L, respectively, the surf-produced aerosol number concentration at the sampling point is similar to the difference in concentration at SCR-PBM and SCR-LBR sites with about $200 \mathrm{~cm}^{-3}$.

Summarizing, it is likely that SSA contributes to the accumulation mode and it is plausible that the WS daily cycle is partly responsible for the differences observed between the marine aerosol concentrations measured in both sites. It is worth pointing out that meteorological data (including WS) were recorded at the INAMHI station at 6:00, 09:00, 12:00, 15:00 and 18:00 LT, and therefore analysis of correlation between these and the marine $\mathrm{N}_{3}$ is not possible. Using the 6:00 LT meteorological values as representative of night time values does not results in significant correlation with $\mathrm{N}_{3}$ at $95 \%$ confidence level. The $\mathrm{N}_{3}$ measurements at SCR-LBR show a correlation of $R=0.44(p=0.046)$ with WS. This tenuous relationship with WS may suggest that it is actually the surf contribution what mostly explains the observed differences between both sites.

\subsubsection{Mixed urban, biogenic and marine aerosols}

The SCR-PBM sampling site is located in an urban site and close to a forested area and therefore both anthropogenic and natural particle contributions to the observed particle concentrations can be expected. The concentration of primary particle pollutants shows weekly patterns, reflecting the day to day variations of the anthropogenic emission activities (Adame et al., 2014). In urban areas, the decrease of human activity during weekend days, which was corroborated 'in situ' during the campaign, produces lower emissions, and therefore lower particle concentrations. With the aim of determining whether there was an urban particle contribution, the differences between the particle concentration during weekdays and weekend days have been analysed.

Fig. 8a shows the daily cycle of mean $\mathrm{N}_{3}$ concentration and solar irradiance during weekdays and weekend days. Weekends showed lower $\mathrm{N}_{3}$ than weekdays between 06:00 LT and 18:00 LT, that is during daytime, when the local human activities were more frequent. It is not possible to differentiate the particle size contribution to the weekend $\mathrm{N}_{3}$ because the particle size distribution was only measured during 1.5 weekends and therefore, the particle concentration within each size range it is not considered as being representative. The marine contribution to the daily cycle of mean $\mathrm{N}_{3}$ can be considered as the average particle concentration from 00:00 LT to 04:00 LT shown in Section 3.1 with $270 \mathrm{~cm}^{-3}$. The biogenic contribution can be represented approximately by the particle concentration during weekends, assuming that the urban influences are negligible. Under this assumption, the urban contribution would be approximately the difference between the particle concentration during weekdays and weekends. Fig. 8b shows the daily cycle of mean $\mathrm{N}_{3}$ concentration, following this classification of particle sources. During the campaign the urban contribution exhibited patterns related to the road traffic intensity near to SCR-PBM, evidencing the strong influence of fresh emissions during (06:00-09:00 LT) and (14:00-15:00 LT).

The daily cycle of the biogenic contribution for $\mathrm{N}_{3}$ concentration is also shown in Fig. 8b. In most environments the peak emission of biogenic volatile organic compounds (BVOCs) is expected to occur at midday (Jardine et al., 2010), but some are also emitted at night. Our observations show that the concentration of newly formed particles at SCR-PBM was observed to be higher before midday. The maximum concentration occurs at 09:00 LT, i.e. $3 \mathrm{~h}$ after the photochemical activity kicks off. This could result from low BVOC concentrations and a lower rate of emission from the vegetation cover than the rate of consumption in the nucleation process. Another explanation may be the accumulation of precursors overnight, contributing to early morning aerosol peaks. A second maximum of the biogenic contribution for $\mathrm{N}_{3}$ was observed during sunset (see below).

The vegetation types at Galápagos Islands vary from desert and desert scrub to mesic evergreen forest, and its distribution is closely associated with the pattern of variation in the local climatic conditions, as well as with variations in altitude and exposure (Hamann, 1979). The back-trajectories plotted in Fig. 2b show that air masses travel over a strip of land before arriving at SCR-PBM. This area is covered by relatively dense desert scrub, containing a high proportion of endemic taxa (Schofield, 1984). There are no studies about the emissions of BVOCs by terrestrial vegetation at the Galápagos Islands. While the research focus has been on forest emissions around the world, very little is known about BVOCs emissions from desert plants and the impact on climate in secondary organic aerosol production (Spracklen et al., 2011). Although higher air temperatures and solar insolation of desert ecosystems may drive high BVOC emissions rates (Jardine et al., 2010), emissions of salicylic ester from desert plants has been suggested to be a significant factor for secondary organic aerosol formation in desert regions (Matsunaga et al., 2008). Emissions of isoprene, monoterpenes and oxygenated compounds from several plant species in the desert regions of the Western USA have been also reported (Geron et al., 2006). Jardine et al. (2010) showed that the BVOCs emissions followed ambient temperature and light and displayed strong diurnal patterns with maxima during midday. However, the ambient concentration of some BVOCs was found to have two maxima: one during midday and a secondary peak late in the evening or midnight. This behaviour could be related to the particle concentration increases during late evening observed in 

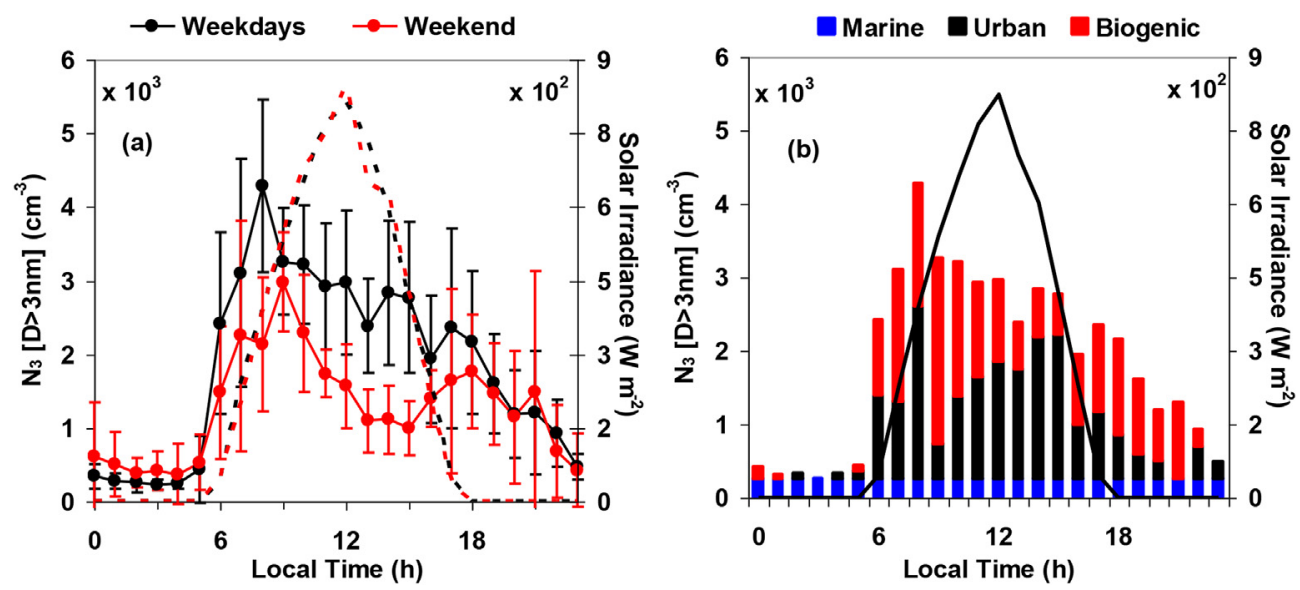

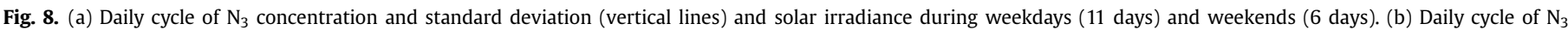
concentration in terms of marine, urban and biogenic particle source and solar irradiance.

Fig. $8 \mathrm{a}$ and $\mathrm{b}$.

The only significant $(p<0.05)$ individual Pearson correlations of $\mathrm{N}_{3}$ (which in daytime is mostly $\mathrm{N} \sim \mathrm{N}_{\mathrm{NUC}}+\mathrm{N}_{\mathrm{NUC}}^{\mathrm{AGE}}$ ) with compositional/meteorological variables are with wind direction, $\mathrm{O}_{3}$ and radiation. As shown in Fig. 2, when the predominant wind is from the S-SW sector $\left(180^{\circ}-225^{\circ}\right)$, the land strip traversed by the air mass is narrow $(2.2 \mathrm{~km})$ and there are no farming activities within the trajectory (the terminal of the Island's airport is the only building in that area). In the S-SE sector $\left(135^{\circ}-180^{\circ}\right)$, where the distance to the coast ranges from $2.2 \mathrm{~km}(\mathrm{~S})$ to $8.4 \mathrm{~km}(\mathrm{SE})$, the island surface is densely covered by vegetation and there are houses and a quarry within the last $1 \mathrm{~km}$ of the air mass trajectory. Ozone plays a role both in urban and biogenic particle formation, and therefore cannot be used to discriminate the two components. Correlation between $\mathrm{N}_{3}$ and $\mathrm{O}_{3}$ anomalies (average of the measurements period subtracted) is significant for daytime daily averages $(R=0.56, p=0.018)$. When only data points within the (S-SE) sector are considered, the correlation coefficient and its level of significance decrease $(R=0.42, p=0.12)$. Thus, the weaker biogenic and anthropogenic sources in the S-SW sector appear to determine simultaneously the variability of $\mathrm{N}_{3}$ and $\mathrm{O}_{3}$. There is indeed a weak correlation between the daily averages of wind direction and $\mathrm{O}_{3}$ $(R=-0.51, p=0.033)$, with $\mathrm{O}_{3}$ levels being lower in the S-SW wind. In the $\mathrm{S}$-SE sector, $\mathrm{N}_{3}$ and $\mathrm{O}_{3}$ concentrations are strongly modified by the biogenic and anthropogenic sources, with different intensities versus time. The correlation between $\mathrm{N}_{3}$ and wind direction was $(R=-0.43, p=0.08)$.

The correlation between $\mathrm{N}_{3}$ and irradiance for hourly averages is strongly significant $\left(R=0.49, p<1 \times 10^{-6}\right)$, since the daily cycle determines both photochemistry and human activities. The correlation coefficient between the average daily profiles (Fig. 8a) of $\mathrm{N}_{3}$ and radiation is $R=0.71$, with $p=1 \times 10^{-6}$. Note that a mismatch exists between the daily cycles, which results in no significant correlation when only daytime data are considered. Consistent with this, no significant correlation remains after subtracting the respective average daily cycles from the two data series. Besides the aforementioned biogenic emission pattern, human activities also affect the shape of the daily $\mathrm{N}_{3}$ evolution, partially decoupling it from the solar irradiance profile. For instance, the early rush hour may be reflected by the abrupt onset around 06:00 LT (black curve in Fig. 8a).

As mentioned above, meteorological data were recorded only five times a day. Therefore, strictly speaking, only $\mathrm{N}_{3}$ data points at these five local times (mixed aerosol category) can be considered for correlation analysis. Still the meteorological data points at midnight can be interpolated using a cubic spline. Since temperature, relative humidity and WS have strong daily cycles depending on irradiance, the interpolated meteorological series also show similar correlations to $N_{3}$. However, yet again the absence of the night-time data renders the correlation between $\mathrm{N}_{3}$ and these variables insignificant. Ozone and wind direction display flat daily cycles, so that time series of daytime data in 3-h intervals can be considered for further analysis by simply removing the full campaign averages. $\mathrm{N}_{3}$ and $\mathrm{O}_{3}$ anomalies remain significantly correlated in this time resolution $\left(R=0.43, p=1 \times 10^{-4}\right)$ and the correlation between $\mathrm{N}_{3}$ and wind direction becomes significant $\left(R=-0.42, p=4 \times 10^{-5}\right)$. Separation of datasets by wind sector reduces the individual correlations although both correlations with $\mathrm{O}_{3}$ and WS remain significant. A multiple linear regression of $\mathrm{N}_{3}$ against $\mathrm{O}_{3}$ and wind direction results in significant coefficients $(p<0.003)$ for both independent variables and a correlation coefficient of $R=0.58$, implying 33\% of explained variance.

Finally, analysis of the correlations between the different modal sizes of the mixed aerosol (six days of measurements, 6:00-23:00 LT) reveals some features of the underlying marine aerosol loading. As could be expected, the anomalies of $\mathrm{N}_{3}, \mathrm{~N}_{\mathrm{NUC}}$, $\mathrm{N}_{\mathrm{NUC}}^{\mathrm{AGE}}$ and $\mathrm{N}_{\mathrm{AIT}}$ are significantly correlated amongst them, with the strength of the correlation decreasing with increasing size difference. Correlation is mostly concentrated in a sub-daily time scale and stems from the variability of the biogenic and anthropogenic sources. However, $\mathrm{N}_{\text {ACC }}$ is only significantly correlated with $\mathrm{N}_{\text {AIT }}$ with a much poorer correlation, and the correlation is due to a negative trend in both six-day anomaly time series, which is not evident in the smallest modes. In fact, the same correlation analysis of the marine aerosol (00:00-4:00 LT) shows that all modal sizes are highly correlated due to this negative six-day trend rather than as a result of sub-daily variability. This simply means that the accumulation mode is exclusively of marine origin, and the poorer correlation between $\mathrm{N}_{\mathrm{ACC}}$ and $\mathrm{N}_{\mathrm{AIT}}$ for the mixed aerosol reflects the contribution of anthropogenic/biogenic aerosol to the Aitken mode. The marine origin of $\mathrm{N}_{\mathrm{ACC}}$ in the mixed aerosol is also indicated by a significant anti-correlation with WS $\left(R=-0.05, p=6 \times 10^{-3}\right)$ which, as mentioned in section 3.2.1, is also observed for the entire data series of $\mathrm{N}_{3}$ using interpolated night time WS data.

\section{Conclusions}

The first measurements of the sub-micron size distribution at the Galápagos Islands are reported. Observations were carried out over a three-week period, with a SMPS particle spectrometer and 
an ultrafine particle counter. The daily evolution observed from 06:00 LT to 23:00 LT is attributed to the contribution of several local aerosol sources, including human activities and emissions from the vegetation of the arid lowlands. The marine particle contribution, observed from 00:00 LT to 04:00 LT was typically a tri-modal number size distribution with peaks near $0.016 \mu \mathrm{m}, 0.050 \mu \mathrm{m}$ and $0.174 \mu \mathrm{m}$ diameter and a cloud-processed intermodal minimum at $0.093 \mu \mathrm{m}$. The mean total aerosol number concentration for the marine contribution was $470 \pm 160 \mathrm{~cm}^{-3}$. No evidence for significant new particle formation in the marine boundary layer was found, being the particle concentration within the nucleation size range of $70 \pm 50 \mathrm{~cm}^{-3}$. A potential explanation of the observed Aitken size range particles is the entrainment of pre-existing aerosol from the free troposphere (FT). According to the analysis of back trajectories, the aerosol enters from the FT off the coast of Chile and it is transported within the MBL to the Galápagos Islands. It is hypothesized here that the accumulation mode is composed of particles previously within the Aitken mode, which become activated and grow through in-cloud sulphate production. The $0.093 \mu \mathrm{m}$ cloud processed minima indicates critical supersaturation (at which the particle is activated to a cloud droplet) in the range $0.14-0.21 \%$. New experimental efforts should be now conducted to characterise chemically the marine aerosol and to measure $\mathrm{CCN}$, which in combination with modelling would enable an evaluation of its impact on the formation of stratus clouds on the windward side of the islands.

\section{Acknowledgements}

M. Sorribas thanks MINECO for the award of a postdoctoral grant (Juan de la Cierva). This work was partially supported by the Spanish Ministry of Science and Technology through project CGL2010-18782 (AMISOC), the Spanish National Research Council (CSIC), the National Institute for Aerospace Technology (INTA) and the Regional Government of Castilla-La Mancha. The authors are grateful to Galápagos National Park for logistic support and the European Union through ACTRIS project (EU INFRA-20101.1.16-262254) for technical support with the SMPS instrument. We also thank the support of NOAA/ESRL for the HYSPLIT backtrajectories.

\section{References}

Adame, J.A., Hernández-Ceballos, M.A., Sorribas, M., Lozano, A., De la Morena, B.A. 2014. Weekend-weekdays effect assessment for $\mathrm{O}_{3}, \mathrm{NO}_{\mathrm{x}}, \mathrm{CO}$ and $\mathrm{PM}_{10}$ in the South Western Europe. Aerosol Air Qual. Res. 14, 1862-1874.

Alpert, L., 1963. The climate of the Galápagos Islands. Occ. Pap. Calif. Acad. Sci. 44 (8), 21-44.

Bates, T.S., Coffman, D.J., Covert, D.S., Quinn, P.K., 2002. Regional marine boundary layer aerosol distributions in the Indian, Atlantic, and Pacific Oceans: a comparison of INDOEX measurements with ACE-1, ACE-2 and Aerosols99. J. Geophys. Res. 107 (D19), 8026. http://dx.doi.org/10.029/2001JD001174.

Blot, R., Clarke, A.D., Feitag, S., Kapustin, V., Howell, S.G., Jensen, J.B., Shank, L.M. McNaughton, C.S., Brekhovskikh, V., 2013. Ultrafine sea spray aerosol over the Southeastern Pacific: open-ocean contributions to marine boundary layer CCN. Atmos. Chem. Phys. 13, 7263-7278.

Carpenter, L.J., MacDonald, S.M., Shaw, M.D., Kumar, R., Saunder, R.W., Parthipan, R. Wilson, J., Plane, J.M.C., 2013. Atmospheric iodine levels influenced by sea surface emissions of inorganic iodine. Nat. Geosci. 6, 108-111. http://dx.doi.org/ 10.1038/ngeo1687.

Clarke, A.D., Owens, S.R., Zhou, J., 2006. An ultrafine sea-salt flux from breaking waves: implications for cloud condensation nuclei in the remote marine at mosphere. J. Geophys. Res. 111 http://dx.doi.org/10.1029/2005JD006565. D06202.

de Leeuw, G., Neele, F.P., Hill, M., Smith, M.H., Vignati, E., 2000. Production of sea spray aerosol in the surf zone. J. Geophys. Res. 105 (D24), 29397-29409.

de Leeuw, G., Guieu, C., Arneth, A., Bellouin, N., Bopp, L., Boyd, P.W., Denier van der Gon, H.A.C., Desboeufs, K.V., Dulac, F., Facchini, M.C., Gantt, B., Langmann, B., Mahowald, N.M., Marañón, E., O'Dowd, C., Olgun, N., Pulido-Villena, E. Rinaldi, M., Stephanou, E.G., Wagener, T., 2014. Ocean-Atmosphere interaction of particles. In: Liss, P.S., Johnson, M.T. (Eds.), Ocean-atmosphere Interactions of
Gases and Particles. Springer, pp. 171-246. http://dx.doi.org/10.1007/978-3642-25643-1 4. Earth System Sciences, Book Chapter.

Draxler, R.R., Hess, G.D., 1998. An overview of the HYSPLIT_4 modeling system for trajectories, dispersion, and deposition. Aust. Meteor. Mag. 47, 295-308.

Ehn, M., Vuollekoski, H., Petäjä, T., Kerminen, V.-M., Vana, M., Aalto, P.P., de Leeuw, G., Ceburnis, D., Dupuy, R., O'Dowd, C.D., Kulmala, M., 2010. Growth rates during coastal and marine new particle formation in western Ireland. J. Geophys. Res. 115. D18218.

Geron, C., Guenther, A., Greenberg, J., Karl, T., Rasmussen, R., 2006. Biogenic volatile organic compound emissions from desert vegetation of the southwestern US. Atmos. Environ. 40, 1645-1660.

Gómez Martín, J.C., Mahajan, A.S., Hay, T.D., Prados-Roman, C., Ordoñez, C., MacDonald, S.M., Plane, J.M.C., Sorribas, M., Gil, M., Paredes Mora, J.F., Agama Reyes, M.V., Oram, D.E., Leedham, E., Saiz-Lopez, A., 2013. Iodine chemistry in the eastern Pacific marine boundary layer. J. Geophys. Res. 118, 1-18. http:// dx.doi.org/10.1002/jgrd.50132.

Gómez-Moreno, F.J., Alonso, E., Artíñano, B., Juncal-Bello, V., Iglesias-Samitier, S. Piñeiro Iglesias, M., López Mahía, P., Pérez, N., Pey, J., Ripoll, A., Alastuey, A., De la Morena, B.A., García, M.I., Rodríguez, S., Sorribas, M., Titos, G., Lyamani, H., Alados-Arboledas, L., Latorre, E., Tritscher, T., Bischof, O., 2015. Intercomparisons of mobility size spectrometers and condensation particle counters in the frame of the spanish atmospheric observational aerosol network. Aerosol Sci. Technol. 49 (9), 777-785. http://dx.doi.org/10.1080/02786826.2015.1074656.

Hamann, O., 1979. On climatic conditions, vegetation types, and leaf size in the Galápagos Islands. Biotropica 11 (2), 101-122.

Heintzenberg, J., Birmili, W., Wiedensohler, A., Nowak, A., Tuch, T., 2004. Structure, variability and persistence of the submicrometre marine aerosol. Tellus Ser. B $56,357-367$.

Heintzenberg, J., Covert, D.S., Van Dingenen, T., 2000. Size distribution and chemicals composition of marine aerosols: a compilation and review. Tellus Ser. B 52, 1104-1122.

Hoppel, W.A., Frick, G.M., Fitzgerald, J.W., 1996. Deducing droplet concentration and supersaturation in marine boundary layer clouds from surface aerosol measurements. J. Geophys. Res. 101, 26553-26565.

Hoppel, W.A., Frick, G.M., Larson, R.E., 1986. Effects on nonprecipitating clouds on the aerosol size distribution in the marine boundary-layer. Geophys. Res. Lett. 13, $125-128$.

Jardine, K., Abrell, L., Kurc, S.A., Huxman, T., Ortega, J., Guenther, A., 2010. Volatile organic compound emissions from Larrea tridentate (creosotebush). Atmos. Chem. Phys. 10, 12191-12206.

Köhler, H., 1936. The nucleus in the growth of hygroscopic droplets. Trans. Faraday Soc. $32,1152-1161$.

Ma, X., Von Salzen, K., Li, J., 2008. Modelling sea salt aerosol and its direct and indirect effects on climate. Atmos. Chem. Phys. 8, 1311-1327.

MacDonald, S.M., Gómez Martín, J.C., Chance, R., Warriner, S., Saiz-Lopez, A., Carpenter, L.J., Plane, J.M.C., 2014. A laboratory characterisation of inorganic iodine emissions from the sea surface: dependence on oceanic variables and parameterisation for global modelling. Atmos. Chem. Phys. 14, 5841-5852. http://dx.doi.org/10.5194/acp-14-5841-2014.

Mahajan, A.S., Gómez Martín, J.C., Hay, T.D., Royer, S.-J., Yvon-Lewis, S., Liu, Y., Hu, L., Prados-Roman, C., Ordoñez, C., Plane, J.M.C., Saiz-Lopez, A., 2012. Latitudinal distribution of reactive iodine in the eastern Pacific and link to open ocean sources. Atmos. Chem. Phys. 12, 11609-11617. http://dx.doi.org/10.5194/acp-1211609-2012.

Mahajan, A.S., Plane, J.M.C., Oetjen, H., Mendes, L., Saunders, R.W., Saiz-Lopez, A. Jones, C.E., Carpenter, L.J., McFiggans, G.B., 2010. Measurement and modelling of tropospheric reactive halogen species over the tropical Atlantic Ocean. Atmos. Chem. Phys. 10 (10), 4611-4624.

Mahajan, A.S., Sorribas, M., Gómez Martín, J.C., MacDonald, S.M., Gil, M., Plane, J.M.C., Saiz-Lopez, A., 2011. Concurrent observations of atomic iodine, molecular iodine and ultrafine particles in a coastal environment. Atmos. Chem. Phys. 11, 2545-2555. http://dx.doi.org/10.5194/acp-11-2545-2011.

Magaritz, L., Pinsky, M., Khain, A., 2010. Effects of stratocumulus clouds on aerosols in the maritime boundary layer. Atmos. Res. 97, 498-512.

Matsunaga, S.N., Guenther, A.B., Potosnak, M.J., Apel, E.C., 2008. Emissions of sunscreen salicylic esters from desert vegetation and their contribution to aerosol formation. Atmos. Chem. Phys. 8, 7367-7371.

McGovern, F.M., Raes, F., Van Dingenen, R.V., 1999. Anthropogenic influences on the chemical and physical properties of aerosols in the Atlantic subtropical region during July 1994 and July 1995. J. Geophys. Res. 104 (D12), 14309-14319.

Mochida, M., Mishita-Hara, C., Furutani, H., Miyazaki, Y., Jung, J., Kawamura, K., Uematsu, M., 2011. Hygroscopicity and cloud condensation nucleus activity of marine aerosol particles over the western North Pacific. J. Geophys. Res. 116 http://dx.doi.org/10.1029/2010JD14759. D06204.

Myhre, G., Bellouin, N., Berglen, T.F., Berntsen, T.K., Boucher, O., Grini, A., Isaksen, I.S.A., Johnsrun, M., Mishchenko, M.I., Stordal, F., Tanré, D., 2007. Comparison of the radiative properties and direct radiative effect of aerosols from a global aerosol model and remote sensing data over ocean. Tellus 59B, $115-129$.

O'Dowd, C.D., de Leeuw, G., 2007. Marine aerosol production: a review of the current knowledge. Phil. Trans. R. Soc. A 365. http://dx.doi.org/10.1098/ rsta.2007.2043.

O'Dowd, C.D., Smith, M.H., 1993. Physico-chemical properties of aerosol over the North East Atlantic: evidence for wind speed related sub-micron sea-salt aerosol production. J. Geophys. Res. 98, 1137-1149. 
O'Dowd, C.D., Mohahan, C., Dall'Osto, M., 2010. On the occurrence of open ocean particle production and growth events. Geophys. Res. Lett. 37 http://dx.doi.org/ 10.1029/2010GL044679. L19805.

O'Dowd, C.D., Smith, M.H., Lowe, J.A., Harrison, R., Davison, B., Hewitt, C.N., 1996. New particle formation in the marine environment. In: Kulmala, M. Wagner, P.E. (Eds.), Nucleation and Atmospheric Aerosols. Elsevier, New York, pp. 925-928.

O'Dowd, C.D., Smith, M.H., Consterdine, I.E., Lowe, J.A., 1997. Marine aerosol, sea salt, and the marine sulphur cycle: a short review. Atmos. Environ. 31, 73-80. http:// dx.doi.org/10.1016/S1352-2310(96)00106-9.

Ovadnevaite, J., Manders, A., De Leeuw, G., Ceburnis, D., Monahan, C., Partanen, A.-I., Korhonen, H., O'Dowd, C.D., 2014. A sea spray aerosol flux parameterization encapsulating wave state. Atmos. Chem. Phys. 14, 1837-1852.

Piazzola, J., Sellegri, K., Bourcier, L., Mallet, M., Tedeschi, G., Missamou, T., 2012. Physicochemical characteristics of aerosols measured in the mediterranean coastal zone. Atmos. Environ. 54, 545-556. http://dx.doi.org/10.1016/ j.atmosenv.2012.02.057.

Prados-Roman, C., Cuevas, C.A., Hay, T., Fernandez, R.P., Mahajan, A.S., Royer, S.-J., Galí, M., Simó, R., Dachs, J., Grobmann, K., Kinnison, D.E., Lamarque, J.-F., SaizLopez, A., 2015. Iodine oxide in the global marine boundary layer. Atmos. Chem. Phys. 15, 583-593.

Raes, F., 1995. Entrainment of free tropospheric aerosols as a regulating mechanism for cloud condensation nuclei in the remote marine boundary layer. J. Geophys. Res. 100, 2893-2903.

Raes, F., Van Digenen, R., Cuevas, E., Van Velthoven, P.F.J., Prospero, J.M., 1997. Observations of aerosols in the free troposphere and marine boundary layer of the subtropical Northeast Atlantic: discussion of processes determining their size distribution. J. Geophys. Res. 102 (D17), 21315-21328.

Russell, L.M., Pandis, S.N., Seinfeld, J.H., 1994. Aerosol production and growth in the marine boundary layer. J. Geophys. Res. 99 (D10), 20989-21003.

Schofield, E.K., 1984. Plants of the Galápagos Islands, New York. Universe Books.
ISBN: 9780876634141.

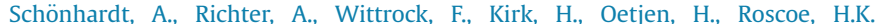
Burrows, J.P., 2008. Observations of iodine monoxide columns from satellite. Atmos. Chem. Phys. 8 (3), 637-653.

Sorribas, M., Adame, J.A., Olmo, F.J., Vilaplana, J.M., Gil-Ojeda, M., AladosArboledas, L., 2015. Long-term study of new particle formation in a coastal environment: meteorology, gas phase and solar radiation implications. Sci. Total Environ. 511, 723-737.

Sorribas, M., De la Morena, B.A., Wehner, B., López, J.F., Prats, N., Mogo, S. Wiedensohler, A., Cachorro, V.E., 2011. On the sub-micron aerosol size distribution in a coastal-rural site at El Arenosillo Station (SW-Spain). Atmos. Chem. Phys. 11, 11185-11206.

Spracklen, D.V., Jimenez, J.L., Carslaw, K.S., Worsnop, D.R., Evans, M.J., Mann, G.W. Zhang, Q., Canagaratna, M.R., Allan, J., Coe, H., McFiggans, G., Rap, A., Forster, P., 2011. Aerosol mass spectrometer constraint on the global secondary organic aerosol budget. Atmos. Chem. Phys. 11 (23), 12109-12136.

Smith, M.H., Park, P.M., Consterdine, I.E., 1993. Marine aerosol concentrations and estimated fluxes over the sea. Q. J. Roy. Meteorol. Soc. 119, 809-824.

Tomlinson, J.M., Li, R., Collins, D.R., 2007. Physical and chemical properties of the aerosol within the southeastern Pacific marine boundary layer. J. Geophys. Res. 112 http://dx.doi.org/10.1029/2006JD007771. D12211.

Van Dingenen, R., Raes, F., Jensen, N., 1995. Evidence for anthropogenic impact on number concentration and sulfate content of cloud-processed aerosol particles over the North Atlantic. J. Geophys. Res. 100, 21057-21067.

Van Dingenen, R., Virkkula, A.O., Raes, F., Bates, T.S., Wiedensohler, A., 2000 A simple non-linear analytical relationship between aerosol accumulation number and sub-micron volume, explaining their observed ratio in the clean and polluted marine boundary layer. Tellus 52B, 439-451.

Zeng, X., Brunke, M.A., Zhou, M., Fairall, C., Bond, N.A., Lenschow, D.H., 2004. Marine atmospheric boundary layer height over the Eastern Pacific: data analysis and model evaluation. J. Clim. 17, 4159-4170. 